Ellen Phelan

ORCID: 0000-0002-3100-5686

Maynooth University, Ireland

ellenpphelan@hotmail.com https://doi.org/10.26881/pwe.2020.50.08

\title{
How can I improve the environment \\ to support the emergent curriculum?
}

\begin{abstract}
Summary
This Action Research (AR) project aims to answer the question "How can I improve the environment to support the emergent curriculum within the toddler room?" It utilises Kemmis and MacTaggart's Action Research Spiral. The researcher, two team members and 24 children aged 18-30 months participated. The research took place in the researcher's place of work: a non-profit community childcare setting. Data was gathered over two cycles of Action Research through observations of the children within the setting, field notes and focus group meetings throughout the project over a six-month period. The project demonstrated the power of the environment to support children's learning and development and to enable them to be the instigators of their own learning. It highlighted the key role of the educator in providing this environment, ensuring it is inclusive and accessible to all children and in engaging in continuous reflective practice as a team with the aim to improve and make meaningful changes. Partnership with parents in creating an environment that supports the diversity of our classrooms also arose as an important finding.
\end{abstract}

Keywords: early childhood curriculum, early childhood environment, emergent curriculum, action research

Słowa kluczowe: program dla dzieci w okresie wczesnego dzieciństwa, środowisko dzieci w okresie wczesnego dzieciństwa, wyłaniający się program, badania w działaniu

\section{Introduction}

As with every year, September 2018 was a busy settling in period for the children, many of whom had just started in the setting. There was a concern that we may struggle to provide a stimulating environment that meets all children's individual needs and interests. The room was sparsely resourced with some objects that did not function and incomplete interest areas. It is a large, bright and airy space with an attached outdoor area however this too lacks resources and equipment. These challenges inspired this Action Research (AR) project. Action Research is recognised as a valuable resource for professionals to engage in a process of collective enquiry, reflect on practice and strive to affect change, whilst also adding to the current discourse and professionalisation of the Early Childhood Education and Care (ECEC) sector (MacNiff, Whitehead 2010). Action Research allows educators to 
investigate the underlying philosophies and theories underpinning their work, questioning if their core values align with their approach (MacNiff, Whitehead 2010; Robert-Holmes 2014). This research aims to uncover how the environment could better align with our core values and the curriculum we provide. The researcher aims to lead the team through a process of critical praxis with the aim to improve practice and provide the children with high quality ECEC experiences.

\section{Literature review}

\section{Image of the child}

Theorists including Maria Montessori, Lev Vygotsky, Vivian Paley and Loris Malaguzzi recognised children as active, self-motivated learners and the importance of the environment for supporting their development and learning (Jones 2012). This is echoed in many international ECEC curriculums today, including Aistear which views children as capable, competent individuals with rights and encourages the creation of a curriculum that reflects this image (NCCA 2009b). The image of the child we hold and the extent to which we value childhood informs the environment we create and the curriculum we provide (Curtis, Carter 2015).

\section{Curriculum}

Aistear advocates for the right of every child to experience a curriculum that is built upon their strengths, needs, interests and cultures (NCCA 2009b). In response, educators devise creative ways to extend learning and development through exploration, play and opportunities to interact with each other within a well-thought-out, carefully considered environment (French 2007; Wurm 2009; Jones 2012). Children engage in their highest form of learning and development through play. It is equally important as a source of uninterrupted enjoyment and fun. Within this safe play space children can explore, think, communicate, take risks, embody different roles from society, demonstrate mastery, problem solve, form understandings, express emotions, be creative and much more (Greenman 2011; Mraz et al. 2016). Play must be a child-led, voluntary endeavour free from adult interference to avoid taking away the very essence of its power (Greenman 2011). The emergent curriculum utilises experiential learning and small group work as children engage in different play scenarios and projects (Sweeney, Fillmore 2018). Educators are required to be knowledgeable, observant and highly motivated to successfully implement an emergent curriculum, actively listening to the children's questions and devising ways to investigate and explore the answers (Hayes 2007; Jones 2012). The curriculum's success is highly influenced by the environment. 


\section{The ECEC environment}

The environment has the potential to inspire and facilitate play and learning, or stifle this creative process. High-quality environments can positively influence children's learning and development (Wurm 2009; Curtis, Carter 2015; Knauf 2018). They should invite children to play, explore, interact, investigate and make choices; nurture independence, and be informed by our image of the child (Wurm 2009; Knauf 2018). They should include a variety of materials and sensory opportunities for exploration and manipulation (Knauf 2018). 'Loose-parts' are a collection of open-ended and purposefully chosen materials which encourage children to use their imagination, follow their emergent interests and find answers to their working theories, supporting their learning and development. They can support the development of critical thinking, innovation, problem solving, early literacy, numeracy and scientific enquiry, provide challenges and endless opportunities (Daly et al. 2015). The Reggio Emilia approach describes the environment as the third teacher, recognising the power of the environment as an active agent in children's learning, and urges educators to examine their environment and question the intention of everything within it (Wurm 2009).

\section{Educator's role}

The educator has a vital role in the development of this environment through meaningful observation and actively listening to the children (Greenman 2011). Children have the right to express ideas and preferences when educators are making changes to their environment; it is therefore important to include them (Curtis, Carter 2015).

When making changes to environments and tackling practice issues, strong leadership is required to overcome barriers and find solutions (Curtis, Carter 2015). All educators within the setting are integral to the provision of high quality ECEC experiences (Dineen 2006). Thus developing a shared leadership approach where educators are encouraged to voice opinions and instigate change can lead to transformational practices (Lee 2010).

Reflective practice allows us to question underlying assumptions and informs our future practice. It is integral to high quality ECEC and central to professionalism (CECDE 2007; Diamond 2014). Critical reflection as a team leads to a deeper understanding of practice issues and allows for different perspectives when questioning practices, values and beliefs (Jarvis et al. 2016). Further, it allows us to align our image of the child and pedagogical beliefs with our everyday practices (Sands 2011).

\section{Inclusion}

Deb Curtis and Margie Carter (2015) warn of the trend towards homogenous ECEC environments, created completely detached from the identity of the children and community they serve. Children need and have the right to see themselves reflected within the 
environment to foster a true sense of identity and belonging (NCCA 2009a; Greenman 2011; Curtis, Carter 2015). Educators must develop an anti-bias environment that respects and acknowledges the diversity of the children and their families (DCYA 2016). Inclusion goes further than merely recognising diversity but seeks to ensure all children are valued, contributing members of the community (Greenman 2011). The children participating in this AR project are from a diverse range of backgrounds with varying degrees of abilities. Therefore there is a need to consider what is required to support them. This requires truly getting to know the children, building strong, reciprocal relationships to discover their individual needs and working in close collaboration with families to decide what is needed to respect and support the children's individuality (Greenman 2011; Palmer et al. 2013; DCYA 2016; Knauf 2018).

\section{Partnership with parents}

Bronfenbrenner's Bioecological Theory highlights the importance of relationships between the different systems which the child is a part of, suggesting that relationships between families and educators directly impact children's learning and developmental outcomes (Keyser 2017). Building respectful, meaningful relationships and fostering parental involvement is central to high quality ECEC (Sims-Schouten 2015). Working in partnership with parents, educators can support the complex, individual needs of every child, respecting the different contexts within which they live (Keyser 2017). When creating an inclusive environment that supports the emergent curriculum, equality of access for all children and their families is an important consideration. Educators must question if the environment is welcoming, respectful and accessible to all. Working in partnership with parents is one of the basic principles of creating an inclusive environment and recognises them as the child's primary educator with valuable insight into the child's 'Funds of Knowledge' (knowledge which the child brings to the setting from home and culture) and information concerning their needs and interests (DCYA 2016).

\section{Study Design: Research Methodology}

\section{Research method: Action Research (AR)}

This project utilised AR: a cyclical process of investigation, reflection and action upon an area of practice. This cyclical process aims to deepen practitioners' knowledge and understanding of current practice leading to meaningful changes (Koshy 2005; Kemmis 2009; MacNiff, Whitehead 2010). It involves critical reflection in collaboration with colleagues to unpack and understand the 'what, how and why' behind practice. AR is contextual and not intended to produce generalisable results (Koshy 2005; MacNaughton, Hughes 2008). 


\section{AR Cycle}

This project utilises 'Kemmis and MacTaggart's Spiral Model of Action Research'. The model involves three stages in each cycle: Plan; Act and Observe; Reflect. A revised plan leads into a new cycle building on the knowledge gained from the previous AR cycle (Koshy 2005).

\section{Sampling}

The sample group for this AR project was the researcher, two team members and 24 children within the toddler room. The children participating were from a diverse range of backgrounds with varying degrees of abilities and levels of development, aged between 18-30 months. This sample group was chosen as this was a small-scale study, based upon the researchers own practice and involving a practice issue which the researcher had the power to investigate and instigate change.

\section{Data Collection}

Data was gathered using focus groups, systematic observations, field notes and reflective practice. Focus Groups intended to engage the team in reflective practice allowing for new ideas and alternative perspectives to emerge, as well as help to mitigate subjectivity and potential bias of an individual researcher (Koshy 2005). Observations provided valuable insights and evidence including on the impact of changes made. Field Notes documented the ongoing research process, recording personal reflections, thoughts and ideas as situations arose.

\section{Data Analysis}

To ensure rigour, it is recommended to use multiple methods of data collection, seek multiple perspectives and follow a systematic approach to the cycles (Koshy 2005; MacNaughton, Hughes 2008). The researcher divided the data into themes as they occurred to allow for analysis and conclusions (MacNiff, Whitehead 2010). The validity of the conclusions was supported by use of critical reflection, collaboration with colleagues and advice from a 'critical friend' (Koshy 2005; MacNaughton, Hughes 2008). The researcher is aware that their personal values and beliefs and that of their colleagues will influence the data gathered and interpretation of its relevance (MacNiff, Whitehead 2010). As such, this research is not intended to be generalised. 


\section{Ethical Considerations}

The researcher obtained permission from the centre and informed consent from the team. Information about the research was provided to parents and informed consent on behalf of their children was obtained ensuring they understood their right to abstain or withdraw. Confidentiality for the centre and participants was upheld using pseudonyms.

There is much debate concerning whether children can give informed consent as they may be incapable of understanding exactly what they are giving consent to and may agree based upon the power imbalance within the teacher-pupil relationship (Koshy 2005; MacNaughton, Hughes 2008; Skånfors 2009). Thus giving simple explanations about the research and observing verbal and non-verbal cues for consent was essential, for example a child removing themselves from play or hiding from view was respected as removing consent (MacNaughton, Hughes 2008; Skånfors 2009). Although the children's photographs informed the analysis, the researcher chose not include them to protect confidentiality.

\section{Limitations}

I wish to acknowledge some limitations to this project from the outset. Further to the lack of generalisability, this project was undertaken within a short time frame therefore one must be realistic about what could be achieved. As it was a non-profit setting, funds for equipment and resources were scarce. The researcher also lacked the autonomy to authorise larger changes to the environment.

Table 1. Cycle One Stages

\begin{tabular}{|c|c|c|}
\hline \multicolumn{3}{|c|}{ Action Research Cycles: Cycle One } \\
\hline Plan $\rightarrow$ & Act and Observe $\rightarrow$ & Reflect \\
\hline - Gather Baseline Data & - Management Meeting & \multirow{6}{*}{$\begin{array}{l}\text { - Focus Group Two: discuss } \\
\text { and reflect upon progress } \\
\text { and observations made } \\
\text { leading to a revised plan }\end{array}$} \\
\hline - Observe Children & - Change layout & \\
\hline - Observe Environment & - Source Materials & \\
\hline - Field Notes & $\begin{array}{l}\text { - Observe Children and } \\
\text { Environment }\end{array}$ & \\
\hline - Focus Group One & \multirow[t]{2}{*}{ - Field Notes } & \\
\hline - Agree Action Plan & & \\
\hline
\end{tabular}

Source: own research.

\section{Reflect and Plan: Focus Group One (FG1)}

The researcher gathered baseline data by taking field notes and observing the children's use of the environment and materials within it. A team FG was held where the researcher reintroduced the research question and observations made so far. The environment and 
room layout arose as a main theme as these did not support the children's play. A second key theme to emerge was materials, which did not support children's play or allow them to follow their interests. Another theme was the lack of funding for materials, which was identified as a potential barrier to the project. An action plan was devised to focus on the construction area as this was a current interest with the children, source materials, meet with management to discuss funding and change the layout of the room.

\section{Actions}

The researcher met with management to discuss funding. The team was allocated time to change room layout and declutter. Over the following weeks, resources were gathered from storage and a couch for our 'cosy corner' was sourced from the charity shop. We requested donations and parents donated recyclables, different lengths of wood, tools and a garage. We received a small grant for materials with which we purchased materials for the construction area.

\section{Observations}

Structured observations of the children using the learning story framework were documented as were unstructured observations through field notes capturing anecdotal observations and reflections. The children were documented engaging in richer play supported by the environment. We documented previously unobserved skills and strengths and made connections to the children's 'funds of knowledge'. Research suggests the environment should invite children to explore and investigate and challenge and encourage them to express themselves through the '100 languages of the child' (Wurm 2009; Knauf 2018).

This was evident in Matt and Patrick's Learning Story which observed them playing in the construction area. Matt arrived that morning with pieces of wood and later that day Patrick joined him in play using the pieces of wood as a 'ladder'. The children demonstrated social and communication skills, confidence, perseverance, problem solving skills, concentration, negotiation skills, early literacy and numeracy skills and initiative as they followed their shared interest in construction. Matt, who is often shy and reserved in groups, demonstrated great leadership and competence in this play. Afterwards the observations were shared with their families. Matt's father was delighted and shared stories of Matt helping him with carpentry work. Patrick's family were also happy and shared that he loved ladders since they put up their Christmas decorations. These observed skills, knowledge and dispositions demonstrate the power of a carefully considered environment in supporting children's learning and development (Knauf 2018). Documenting and sharing learning with families gave us a valuable insight into the children's interests and supported our decision to focus on the construction area. This is recognised as an important way to create connections and develop strong relationships, key to supporting children's holistic development (SimsSchouten 2015; Keyser 2017). In the Field Notes, the construction area was also observed 
as a 'hub of activity' supporting the children's developing social skills as they explored new equipment and demonstrated 'funds of knowledge' as they played.

\section{Reflection and Planning: Focus Group Two (FG2)}

In FG2 the team reflected upon changes, observations and progress so far. Funding again arose as a key theme. Educators were disheartened by insufficient budget allocation for materials and these concerns were shared by other teams in the centre. Educator 1 stated: "It's quite frustrating that the board asked for a smaller list, we are only looking for the basics (...) we have all bought things out of our own pocket (...) nobody is in a position to buy the bigger resources themselves".

Materials reemerged as a theme highlighting the need to be selective with the materials introduced. The open-ended materials were most successful to engage children's imagination (Daly et al. 2015). Educator 2 noted: “A few simple bits really sparked their interest (...) look at them outside (...) there is nothing - stones, grass, slides and they are so capable out there, totally engrossed in play. What does that tell us? That less is more (...) wood, sand, rice trays, cartons, scarves are such a big hit (...)".

Inclusion also emerged as a theme, questioning how best to ensure that the environment supported the complex needs and interests of all the children in our room. Educator 1 noted: "David (who has autism) is a bit overwhelmed; he seems to be moving quickly from the different areas, disrupting their play, knocking things down, if he's engaged in play and too many people join him, he leaves". The researcher added: "I noticed this with Kayden as well, he is busy playing or trying to engage with the materials but as soon as too many children are involved, he moves away. I'm trying to support his language but often when I'm engaging with him it encourages other children over and he loses interest'.

Table 2. Cycle Two Stages

\begin{tabular}{|c|c|c|}
\hline \multicolumn{3}{|c|}{ Action Research Cycle Two } \\
\hline Plan & Act and Observe & Reflect \\
\hline $\begin{array}{l}\text { - Discuss funding and } \\
\text { resources with centre staff }\end{array}$ & - Meet with centre staff & \multirow{6}{*}{$\begin{array}{l}\text { - Focus Group Three: } \\
\text { Discuss progress and } \\
\text { observations made, } \\
\text { leading to a revised plan }\end{array}$} \\
\hline $\begin{array}{l}- \text { Discuss funding with } \\
\text { management }\end{array}$ & - Meet with management & \\
\hline $\begin{array}{l}\text { - Create a space where } \\
\text { children to escape the crowd }\end{array}$ & - Focus on 'cosy corner' & \\
\hline \multirow[t]{3}{*}{$\begin{array}{l}\text { Introduce open ended } \\
\text { materials and declutter }\end{array}$} & $\begin{array}{l}\text { - Declutter and introduce open } \\
\text { ended materials }\end{array}$ & \\
\hline & $\begin{array}{l}\text { - Observe children and the } \\
\text { environment }\end{array}$ & \\
\hline & - Field notes & \\
\hline
\end{tabular}

Source: own research. 


\section{Revised plan}

Cycle 1 reflections led to a revised action plan to meet with centre staff about budget concerns and management again to discuss this; declutter and add open-ended materials and have a conversation with parents of children with additional needs to share ideas about how best to support them. We chose to focus on creating a quiet space for children to escape to by improving the cosy corner.

\section{Meetings}

Staff throughout the setting also reported buying materials themselves or bringing them from home. Staff suggestions arose such as creating a shared resource cupboard to swap out things as the children's interests change. The researcher met with management to discuss feedback. Management agreed with the suggestions. They acknowledged the demands of securing centre funding left little time to reflect on whether the rooms were equipped to support the curriculum. Management agreed to take feedback and suggestions to the centre director.

An informal team meeting was held to discuss David and Kayden's progress. Following discussion with David's parents and occupational therapist visual cues alongside our songs for transitions were introduced. They also supported our decision to focus on the cosy corner as an area to escape to. Research demonstrates building close relationships with families and actively seeking ideas and input when creating an inclusive environment is important (NCCA 2009b; DCYA 2016).

\section{Further actions}

The team questioned the intention of each resource and de-cluttered to allow the children to retain their focus and engage in undisturbed play (Curtis, Carter 2015). A shared resource cupboard was set up from which we found curtains and lights to frame our cosycorner, a sensory light table and items from the government's 'Access Inclusion Model' pack which includes resources to support children with additional needs. We added openended sensory materials such as shells, pine cones, cardboard tubes and sensory boxes.

\section{Observations}

Visual cues proved successful during transitions for all the children, as did the changes to the cosy corner. Educators observed children playing in the cosy corner, following an interest, sharing their experiences and using their initiative. Field notes observed: The children are enjoying making a den beside the couch with the curtains as a roof. The children are also using the curtains to create a tent, they set off to get sleeping bags and before long they are all lying down camping, the educator sets up a small 'fire' and reads stories 
to the children, they giggle and chat and fall 'asleep'. Educator's also observed the use of the cosy corner as a space of quieter small group play. Further, the improvements to the environment allowed activities to be set up to meet the complex needs within the room. For example, Educator 1 set up the light table and David engaged with her for 30 minutes whilst the other children were busy exploring other areas of the room, some children joined and once the table was full (4 children) others were asked to wait and assured that they would get a turn soon, this worked well.

\section{Reflection: Focus Group Three (FG3)}

At FG3, the team discussed observations and reflected on progress. Funding and materials arose again as key themes. Management announced each room would be allocated a small monthly fund for materials which must be spent each month before receiving the next payment. Although this was welcomed, there was concern that this would only allow the purchase of smaller materials. Educator 1 stated: "This is a start I suppose, it's a shame to be getting it in small amounts. If we saw a really nice piece that was a bit more expensive and might last longer, we can't get it". However, Educator 2 felt: "It is better than nothing and our outdoor area needs a lot of attention'. The team discussed the success of sharing materials with other rooms and planned to focus on the outdoor area next. They also reflected on the benefit of the improved cosy corner". Educator 2 recognised: "Having the cosy corner to read books on the couch with small groups is lovely it's away from the crowd and you can really spend that time working with just a few children". The team then used Curtis and Carter's (2015) observation "assessing from the child's perspective". This involved drawing a diagram of the room and answering questions about the environment from the child's perspective. This led to further areas to focus on next demonstrating the continuous cyclical process of AR and the fact that each cycle will lead into the next (Koshy 2005).

\section{Discussion}

\section{Image of the child}

Our image of the child is reflected in the environment we create and curriculum we provide (Jones 2012). This is apparent in Cycle 2 Field Notes: "The children are using the curtains to create a tent. They set off to get sleeping bags from our sleep room and before long they are all lying down camping". The environment is flexible and the children are free to follow their own interests and enquiries, supporting our image of children as active agents in their own learning who should be provided with opportunities for independence and autonomy (NCCA 2009a). 


\section{Environment supporting an emergent curriculum}

These research findings support the assertion that the environment can inspire or stifle play and support children to follow their emergent interests. This is evident in Matt and Patrick's Learning Story for example when the improved construction area and addition of new materials inspired richer play episodes (Wurm 2009; Curtis, Carter 2015; Knauf 2018). This was in contrast with initial Field Note observations which demonstrated the insufficient materials available were not holding the children's interest or supporting their play.

Lisa Daly et al. (2015) argued that the addition of loose parts provides endless opportunities for children to manipulate the materials to follow their emergent interests. As observed by Educator 1 in FG2: "A few simple bits really sparked their interests (...) totally engrossed in play (...) wood, sand, rice tray, cartons, scarves are such a big hit". This was further supported in Matt and Patrick's Learning Story observation where Patrick imagined planks of wood to be a ladder in his play. Matt and Patrick's observation also illustrated how high quality environments can facilitate children's development and learning when for example Matt demonstrated leadership skills and competencies not previously observed (Wurm 2009; Curtis, Carter 2015; Knauf 2018).

These research findings also supported Helen Knauf's (2018) assertion that well-designed spaces encourage children's participation, exploration and interaction. As observed in Cycle 1 Field Notes the improved construction area became a 'hub of activity' supporting the children's developing social skills, as did the 'cosy corner', which was transformed into a 'campsite' with the children engaging in imaginary play scenarios together.

\section{Educator's role}

Lorraine Sands (2011) and Pam Jarvis et al. (2016) theorised that reflective practice as a team can facilitate a collaborative approach and a shared vision for practice. This was evident through collective reflective practice during FG's and meetings where each educator identified frustrations, and challenges but also ideas and valuable insights, which were incorporated into practice.

Research suggests a shared leadership approach encouraging all educators' involvement in decision making can help overcome barriers and lead to meaningful change (Lee 2010). This was evident in our FG and centre meeting where we worked together as a team, each suggesting solutions to overcome budget constraints. This led to a shared resource cupboard, sourcing materials from the charity shop and parents, and discussions with management, resulting in a new budget for materials. These changes supported our emergent curriculum leading to high quality ECEC experiences (Dineen 2006; Curtis, Carter 2015).

Curtis and Carter (2015) discuss the importance of including the child's voice when making changes to their environment. Considering the age and varying levels of development, the researcher chose to gather the children's preferences and ideas through careful 
observation of their play and interactions within the environment. This proved to be a valuable way to capture both verbal and non-verbal preferences, emergent enquiries and developmental needs.

\section{Inclusion}

Creating an inclusive environment requires educators to consider what changes may be needed to support children's individual developmental needs (Greenman 2011; Palmer et al. 2013; DCYA 2016; Knauf 2018). Research demonstrates the importance of creating an environment which reflects the diversity and meets the complex needs of all children within the room to ensure all children can participate in the emergent curriculum (Greenman 2011; DCYA 2016). This was evident in this research when educators encouraged children to utilise the cosy corner as a quiet area to 'escape the crowd' by enclosing the area and incorporating lights and sensory materials for example. In this area, David and Kayden benefitted from small group time without distraction or overstimulation. This facilitated educators to follow their needs and interests and support their language and communication in small groups.

\section{Partnership with parents}

Research asserts strong partnerships with parents, seeking their input and ideas supports learning and development (Hayes 2007; NCCA 2009b; Keyser 2017). This could be seen when Matt's father donated planks of wood for our construction area and informed us of Matt's interest in carpentry at home providing invaluable insight into his 'funds of knowledge'. This insight informed the curriculum planning to support Matt's social and emotional development. This demonstrated Matt's father working in partnership with the team to support Matt's learning and development using his emergent interests.

\section{Conclusions}

Although this small scale AR project is not generalisable to other settings, it demonstrated the value of AR cycles, each learning from and building on the last to deepen learning and better support educators to improve practice. Data gathered for this project demonstrated the power of the environment to support the emergent curriculum and thus children's learning and development. Small changes illustrated the potential of the environment to invite children to explore, play and follow their emergent interests which can encourage the development of new ideas, skills, knowledge and dispositions (Curtis, Carter 2015). This research reinforced Reggio Emilia's assertion that the environment is the 'third teacher'. It highlighted the power of educators collaboratively engaging in purposeful observations to truly listen to the child's needs and emerging interests (Hayes 2007; Jones 2012). Reflective practice proved to be invaluable, encouraging the team to critically reflect on how the 
environment could be improved to support the emergent curriculum in a meaningful way. This called for the team to work collaboratively towards a child led, shared vision for the environment. As early childhood educators who aspire to ensure that all children have access to high quality ECEC experiences within inspiring ECEC environments, AR can act as a vehicle to create such an environment where all children can thrive.

\section{References}

CECDE (Centre for Early Childhood Development and Education) (2007), Siolta Research Digest Standard 7: Curriculum. http://www.ncca.ie/en/Practice-Guide/S-olta/Building-ResearchDigests-linked-to-the-above-Standards.pdf, 8.10.2018.

Curtis D., Carter M. (2015), Designs for Living and Learning: Transforming Early Childhood Environments. $2^{\text {nd }}$ ed. St Paul, Redleaf Press.

Daly L., Beloglovsky M., Daly J. (2015), Loose Parts Inspiring Play in Young Children. St. Paul, Redleaf Press.

DCYA (Department of Children and Youth Affairs) (2016), Diversity, Equality and Inclusion Charter and Guidelines for Early Childhood Care and Education. http://aim.gov.ie/wp-content/uploads/2016/06/Diversity-Equality-and-Inclusion-Charter-and-Guidelines-for-Early-ChildhoodCare-Education.pdf, 10.11.2018.

Diamond A. (2014), Pre-service early childhood educators' leadership development through reflective engagement with experiential service learning and leadership literature. "Australian Journal of Early Childhood", 39(4).

Dineen F. (2006), How Professionalism Defines the Effective Educarer: A Reflection on the ThemeTraining for a New Profession. In: OMEP Conference. St. Patrick's College, Drumcondra, $23^{\text {rd }}$ April, 2005. Dublin, DIT. https://arrow.tudublin.ie/cgi/viewcontent.cgi?article=1026\&context= csercon, 17.03.2019.

French G. (2007), Children's Early Learning and Development, Research paper. Dublin, National Council for Curriculum and Assessment.

Greenman J. (2011), What all Children Need, Extract From: Caring Spaces, Learning Places. http:// www.communityplaythings.com/resources/articles/2011/what-all-children-need, 3.12.2018.

Hayes N. (2007), Perspectives on the Relationship Between Education and Care in Early Childhood, Research paper. Dublin, National Council for Curriculum and Assessment.

Jarvis P., George J., Holland W., Doherty J. (2016), The Complete Companion for Teaching and Leading Practice in the Early Years. $3^{\text {rd }}$ ed. Oxon, Routledge.

Jones E. (2012), The Emergence of the Emergent Curriculum. "YC Young Children", 67(2).

Kemmis S. (2009), Action Research as a Practice Based Practice. "Educational Action Research", 17(3).

Keyser J. (2017), From Parents to Partners, Building a Family Centred Early Childhood Programme. Maynooth University Library, https://ebookcentral.proquest.com/lib/nuim/reader. action?docID=5267896, 8.12.2018.

Knauf H. (2018), Visual Environmental Scale: Analysing the Early Childhood Education Environment. https://link-springer-com.jproxy.nuim.ie/article/10.1007\%2Fs10643-018-0914-x, 15.12.2018. 
Koshy V. (2005), Action Research for Improving Practice: A Practical Guide. London, Paul Chapman Publishing. Maynooth University Library, https:/ebookcentral.proquest.com/lib/nuim/ reader.action?docID $=343982 \&$ query $=, 14.10 .2018$.

Lee W. (2010), Leading with Heart and Soul: using magic, being moral, creating merriment and mobilising others. http://elp.co.nz/EducationalLeadershipProject_Resources_Articles_ELP.php, 17.03.2019.

MacNaughton G., Hughes P. (2008), Doing Action Research in Early Childhood Studies: A Step by Step Guide. New York, Open University Press.

MacNiffJ., Whitehead J. (2010), You and Your Action Research Project. $3^{\text {rd }}$ ed. Oxen, Routledge. Maynooth University Library, https://ebookcentral.proquest.com/lib/nuim/reader. action?docID $=446724 \&$ query $=, 7.10 .2018$.

Mraz K., Porcelli A., Tyler C. (2016), Purposeful Play: A Teachers Guide to Igniting Deep and Joyful Learning Across the Day. Portsmouth, Heinmann. https://www.vcsd.k12.ny.us/cms/lib/ NY24000141/Centricity/Domain/1073/Purposeful\%20play\%20exerpt.pdf, 8.10.2018.

NCCA (National Council for Curriculum Assessment) (2009a), Aistear: The Early Childhood Curriculum Framework. Dublin, NCCA.

NCCA (National Council for Curriculum Assessment) (2009b), Aistear: The Early Childhood Curriculum Framework, Key Messages from the Research Papers. Dublin, NCCA. http://www. ncca.biz/Aistear/pdfs/KeyMessages_ENG.pdf, 8.10.2018.

Palmer S., Summers J.A., Brotherson M.J., Erwin E.J. (2013), Foundations for Self-Determination in Early Childhood: An Inclusive Model for Children with Disabilities. "Topics in Early Childhood Special Education”, 33(1).

Roberts-Holmes G. (2014), Doing Your Early Years Research Project: A Step by Step Guide. $3^{\text {rd }}$ ed. London, Sage Publishing.

Sands L. (2011), Self-Review - questioning our practice through thoughtful investigation. http:// elp.co.nz/EducationalLeadershipProjectResourcesArticlesELP.php.http://elp.co.nz/EducationalLeadershipProjectResourcesArticlesELP.php, 1.04.2019.

Sims-Schouten W. (2015), Positioning in relationships between parents and early years practitioners. "Early Childhood Development and Care", 186(9).

Skånfors L. (2009), Ethics in Child Research: Children's Agency and Researchers ' Ethical Radar'. "Childhoods Today", 3(1).

Sweeney S.J., Fillmore R. (2018), The Birds, The Children, The Big Black Dog: Reflecting on Emergent Curriculum. "YC Young Children", 73(1).

Wurm J. (2009), How the Environment Inspires the Curriculum. http://www.communityplaythings. com/resources/articles/2009/how-the-environment-inspires-curriculum, 3.12.2018. 